\title{
THE POLAR BEAR AND ITS PROTECTION
}

\section{By ALAN G. LougirREY}

\section{Canadian Wildlife Service}

The polar bear, Thalarctos maritimus, (Phipps) enjoys such colloquial names as : "ice-bear," "sea-bear," "ice-tiger" and " ice-king." In view of its large size and its supremacy over the other beasts of the ice-floes it well deserves these epithets. Primarily the polar bear is an animal of the broken aretic pack ice and is found in greatest numbers along the southern edge of the pack. It avoids large expanses of open water or frozen sea ice. The movements of the pack ice to a large degree determine its distribution and movements. Polar bears are carried southward with the pack ice in the spring and summer. In August and September when the ice begins to break up they generally come ashore and make their way north. At this time of year they may be found in considerable numbers along certain coasts where the sea ice has been brought by the winds, tides and currents. An Eskimo from Southampton Island, in northern Hudson Bay, informed me that in August, 1948, he and a companion counted over 180 of these bears along the east coast of that island.

This bear is of circumpolar distribution and is found in all arctic and many subarctic seas and coastlines. In North America it is found from Alaska to Labrador and from southern James Bay to northern Ellesmere Island. It is relatively common on the pack ice off the Alaskan coast north of Bering Strait as well as in Beaufort Sea and Amundsen Gulf. It is less common along the central arctic coast from Coronation Gulf to the west side of Boothia Peninsula. In this area, because of the decreased effects of tides and currents, the sen ice freezes over more or less solidly. To the east of Boothia Peninsula bears become more common. In Fudson Bay they are most common at the northern end, in the vicinity of Southampton Island. However, they occur along all coasts of this bay and James Bay where they are found on the offshore islands. In the " high aretic" they occur throughout the Aretic Archipelago. They also frequent the pack ice off the west and east coasts of Greenland. Stragglers are occasionally brought by the drifting ice floes to Iceland. In Europe and Asia these bears inhabit the ice fields of the Arctic Ocean, Barents Sea and the region from arctic Norway to Wrangel Island.

The polar bear is one of the largest of the terrestrial carnivores and is exceeded in size only by the Big Brown Bear, Ursus 
middendorffi, of Alaska. In body form the polar bear is somewhat more streamlined than a grizzly bear. It is proportionately longer-bodied, with a longer neck and narrower, less massive skull and it has smaller ears than a grizzly. The males are from one-third to one-quarter larger than the females and attain body lengths of over eight feet and weights from 900 to 1,100 pounds. The greatest weight recorded for a polar bear is 1,600 pounds. Both sexes retain their white or yellowish white coats throughout the year.

In the late autumn the pregnant female polar bears seek places to den. They choose snowbanks formed in the rough pressure ice or on the lec side of a hill. In the den which has been excavated in the hardpacked snow, the female gives birth to her cubs. The cubs, usually two in number, but occasionally one or three, are born from late November to early January. They arc small, weighing less than two pounds, naked and blind, at birth. The female continues to suckle them throughout the long aretic night. She leaves the den in March with her cubs, which by this time are about two feet long, weigh 20 pounds and are covered with crinkly white fur. If she has denned on land she leads her cubs directly to the coast and sea ice. The Eskimos call these young cubs ah tik tok, which means "those that go down to the sea". On the land-fast ice of the sheltered bays along the const she hunts out the snow caves or igloos where the female ringed seals, Phoca hispida, give birth to and tend their young, white-conted pups. Later in the spring she hunts these scals as they lie basking on the sea ice beside their enlarged breathing holes.

The yearling cubs may stay with their mother during the second summer, by this time they are nearly half-grown and weigh between 200 and 400 pounds. The female is ready to mate again during this summer and may drive the cubs away or leave them behind. Some time during this period she mates, but little is known of the courtship and mating activities. Late in the autumn she seeks out a den site and is ready to bring forth another litter of cubs. The female polar bear becomes sexually mature at five and a half years of age. A female kept in captivity lived for 35 years, first bred at six years of age and produced 12 cubs, all on alternate years.

The polar bear is more nearly carnivorous in its food habits than most other bears. Its chicf food item is the ubiquitous ringed seal. Other foods include: the walrus, other arctic seals, carrion, fish, birds and their eggs, and grass. It captures seals by stalking them as they lie basking on the sea ice; its white 
coat provides an excellent camouflage. It also catches seals that happen to be slecping near the edge of the ice by swimming towards them underwater and then suddenly rising out of the water to crush their skulls with a blow from its powerful forearm. Bears have also been reported to dive under the solid bay ice to capture a seal at its breathing hole. In spite of their strength and cunning these bears hesitate to attack adult walruses. They do, however, prey upon walrus ealves and young animals.

Large numbers of these bears will often congregate in the vicinity of the carcass of a stranded whale or walrus. Recently the carcass of a Bowhead whale, Balaena mysticetus, was washed ashore on the northeast coast of Southampton Island. A local Eskimo informed me that he and some friends had come upon this carcass while travelling by dogteam and had counted 42 polar bears in the immediate vicinity of the stranded whale.

In the late summer polar bears are frequently found on the offshore islands or along the coast; at this time they are often grazing on grass or other vegetation. It has been reported that these bears eat fish as well as seabirds, waterfowl and their eggs, but these items probably form only a minor part of their diet. Mr. Graham Cooch, of the Canadian Wildlife Service, informed me that on one occasion he watched a large bear walk through a colony of nesting snow and blue geese without disturbing a nest, nor did it pay any apparent attention to the birds.

Polar bears are quite nomadic by nature and cover many miles either passively by drifting with the pack ice or actively when returning northward. They generally follow the constline when travelling on land, but do not hesitate to cross considerable stretches of land. In August of 1952 I saw a large bear, which was more than $\mathbf{3 0}$ miles from the nearest coast, heading north on Melville Peninsula.

As the name " sea-bear" implies, this bear is quite at home in the water, being able to dive as well as swim. It swims rather slowly, using only its forefect and legs to propel itself ; the hind limbs are trailed behind. It may swim with its muzzle extended, but when the water is rough I have noted that they swim with the muzzle, including the eyes, submerged, lifting their head only from time to time to breathe. They apparently feel more secure on the sea ice or in the water than on land and almost invariably head for the sea when disturbed by man.

There are many stories pertaining to the ferocity of the polar bear. 'This ferocity, as might be expected, seems to vary from individual to individual and also from season to season. During 
the summer months most bears are rather timid and attempt to avoid contact with man. In the winter months they appear to be more inquisitive and aggressive. They may have gained this reputation partly from the actions of bears that have drifted down from far northern regions and have had no previous contact with man and hence have no reason to fear him. It is perhaps bears such as these which occasionally stalk and attempt to kill native hunters when they are hunting on the sea ice. A female bear with cubs will normally attempt to lead them to safety, but as might be expected will fight fiercely if she believes that they are in danger. Wounded bears, of course, are dangerous animals. It is a wise and agile Eskimo dog that survives many encounters with a polar bear.

There has been a certain amount of controversy concerning the polar bear's habit of "hibernation". Like other bears their's is not a true hibernation, but merely a prolonged, deep sleep during the winter months. It has been stated by some authors that only pregnant females go into snow dens to sleep through the winter. Others claim that both sexes hibernate. It seems likely to me that both of these hypotheses.are to a certain extent correct. In areas where the sea ice freezes over and there are no open leads of water and suitable hunting areas, the male bears also appear to come ashore and den in the snow banks. The duration of their denning period is short and varies considerably, but appears most commonly to be throughout December and January. I believe that this is the case in Southampton Island as I have seen fresh tracks of these bears as they headed out to the sea ice from land in early February. In other areas where there is much broken pack ice with open leads and good hunting for seals, the male bears appear to spend the winter hunting in this rough ice. During unusually severe weather or blizzards they may den up in snow drifts in the pack ice for several days.

The natural causes of mortality of the polar bear appear to be relatively few in number. Its only predator is the bear itself, as adult males will, if given the opportunity, kill and eat the cubs. Occasionally a bear will attack an adult walrus and come out second best. Several explorers have found dead bears which appeared to have been gored by walruses.

The diseases and parasites of this animal are not well known. They are infected with trichinosis, but the general debilitating effect of this parasite is not known. Other diseases may include mange and rabies; however, since these animals are not normally social there is little opportunity for the transmission 
of these communicable diseases. A few bears are probably killed at sea by drowning or crushing during severe storms when the polar pack ice may become a hazard rather than a haven.

The polar bear or nanooli of the Eskimos has always played an important part in the culture of the coastal Eskimos. It occupies the place in their legends that the wolf does in the legends of the North American Indians. Primitive hunting of the polar bear was a hazardous occupation and to kill one of these animals was a mark of distinction for the hunter. In the winter an Eskimo might hunt bears by chasing them with his dogteam. When the team commenced to overtake the bear he would cut one or several of his dogs free of the sled so that they might run ahead and hold the bear at bay. When the bear was at last brought to bay the hunter approached and attempted to kill it with his long-handled lance while the dogs kept it preoccupied. There are even stories of famous hunters, armed only with a long-bladed snow knife, who were able to kill a bear by ducking under the raking claws of the upright bear to stab and fatally wound it. In the summer they killed swimming bears from their kyaks.

At present some of the northern Eskimos still hunt bears in the winter with their dogteams, but they now use a high powered rifle rather than a lance to deliver the coup de grâce. In certain areas where bears are known to den year after year the Eskimos make special hunts for them in the winter. Dogs are used to sniff out the breathing hole in the snow above the bear's den. The hunter then digs a small trench into the den and after locating the head of the sleeping bear promptly dispatches it. Some enterprising hunters partly dig out a tunnel, arouse the bear and then wait until it emerges from its den before killing it, thus saving themselves the trouble of dragging the heavy carcass out of the den.

The Eskimos formerly utilized the bear's hide in numerous ways ; fine waterproof pants, boot bottoms, bedding robes and sledge covers were made from this skin. The long canine teeth were valued as ornaments. At present less use is made of the bear skin as an article of clothing because it is heavy and difficult to sew, but these fine robes still find their use in the Eskimo economy. By far the most important value of the bear to the Eskimo is for the meat which is consumed by both humans and dogs. 'The meat, although rather stringy, is regarded as quite palatable and is a welcomed change from a seal or walrus meat diet.

The liver of the polar bear is poisonous and most Eskimos do 
not even feed it to their dogs. This poisonous quality has been found to result from an extremely high concentration of vitamin A. A person who eats this liver usually suffers from hypervitaminosis with resulting headache, nausea and occasionally peeling of the skin. The toxicity of the liver varies from bear to bear, apparently depending upon the relative concentration of vitamin $A$.

During recent years with the increasing number of visitors to the arctic the demand for polar bear skins has increased. Skins are sold locally for $\$ 15$ to $\$ 50$ or more, depending upon the locality and primeness of the skin; cub's skins usually bring $\$ 10$ or less. It is estimated that 100 skins are shipped annually from Alaska. In Canada, approximately 400 polar bears are taken each year by the Eskimos. Of this total nearly 20 per cent are retained by the Eskimos for their own use. This bear is also of some value to the Indians who inhabit the southern shores of Iudson and James bays. Each year they kill a few bears that are brought to shore by the ice floes or that wander inland to den in the snowbanks which form along the rivers that empty into the bay. The Indians normally use the meat from these animals for dog food.

No census has been made of the polar bear population and indeed the general movements of the animals within their range are poorly known. At present it is not possible to determine whether the population is being under or over harvested. To date there does not appear to have been any appreciable change in the range of this animal. It is still quite common on eastern Baffin Island, Southampton Island, the Gulf of Boothia and the northern aretic islands. Perhaps the only feasible method at present to determine the population trends of this animal will be to continue to gather information relative to the total harvest and observe to what extent this harvest is maintained under the present hunting pressurc. There is no sport-hunting of the polar bear in Canada, only Eskimos and Indians are allowed to hunt them. The open season for polar bears in the Northwest Territories is from 1st October to 31st May; a period which coincides with the time that their skins are prime.

If and when it is determined that the numbers of the polar bear are being excessively reduced it will be necessary to take steps to prevent their further reduction and to allow the population to increase. One such step that might be taken would be to prohibit the export of polar bear skins from the Northwest Territories. This would not create any real hardship for the Eskimos since they would be able to continue to take bears for 
their own use, but it would discourage market hunting. Another alternative might be to set aside as sanctuaries regions where large numbers of bears, especially females with their cubs, are known to den. In managing the population of these animals for the benefit of the Eskimos, to whom they rightly belong, it must always be remembered that, in their present economy based on hunting and trapping, the meat of the polar bear is of more importance to them than the money that they might derive from the sale of skins. Before it is possible to manage intelligently the polar bear population in accordance with the sustained yield concept, it will be necessary to gather further data relative to the numbers, population trends and life history of this animal.

\section{BIBLIOGRAPIIY}

Bnown, M., B. Cronk, F. DeSinner, J. E. Green, J. E. Ginbons and E. KuITUNEN-EKBaUM. $\Lambda$ note on trichinosis in animals of the Canadian Northwest Territorics. Can. J. Pub. Ilealth 40: 20-21. 1040.

BurT, W. II. and R. P. Grossenimisen. A field guide to the manimals, pp. 1-200. Houghton Mimlin Co., Boston, 1052.

Caitalane, V. H. Mammals of North America, pp. 1-682. Macdillan Co., New York. 1047.

Milfer, G. S. and R. Kelzoga. List of North American recent mammals. U.S. Nat. Mius. Bull. 205.1055.

Nelson, E. W. The larger North American mammals. Nat. Geog. Mag. 30 : 385-472. 1016.

Premer, E. A. A biological investigation of the Hudson Bay region. U.S. Dept. Agric. Div. of Biol. Surv. N.A. Fauna 22. 1002.

$-A$ biological investigntion of the Athabaska-Mfackenzic region. U.S. Dept. Agric. Bur. of Bio. Surv. N.A. Fauna 27. 1008.

Resiey, O. E. Sultana, polar bear queen. Nat. Mag. 40 : 420-30, 4.42 .1947$.

RuOdE, C. J. and W. BAnken. Alaska's fish and wildlife. U.S. Dept. of Interior, Fish and Wildlife Service. Circ. 17. 1053.

RoDsin, IK. and T. Moone. The vitnmin $A$ content and toxicity of bear and seal liver. Biochem. J. 37 : 160-168. 1043.

SEron, E. T. Lives of Game Animals. 2 : 1-367. Doubleday and Doran Co., Inc. Garden City, New York. 1020.

Sopen, J. D. $\Lambda$ faunal investigation of southern Bamin Island. Nat. Mlus. of Can. Bull. 53. 1028.

Sutron, G. MI. and W. J. HAsiluton, Jr. The mammals of Southampton Island. Mem. Carnegie MIus. Vol. 12, P't. 2, Sect. 1. 1032. 